UNIO - EU Law Journal. Vol. 6, No. 2, July 2020, pp 15-24.

®2020 Centre of Studies in European Union Law

School of Law - University of Minho

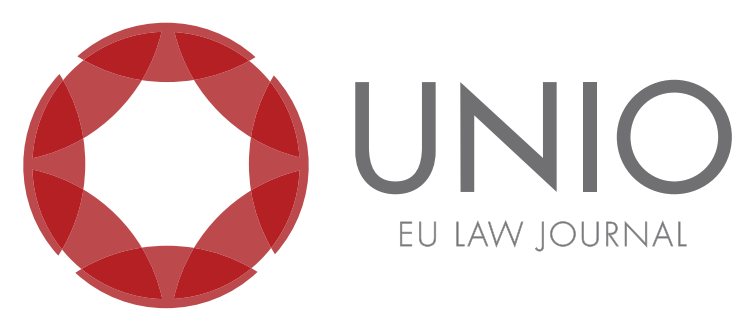

\title{
Revisiting access to internet as a fundamental right in times of COVID-19
}

\section{Mariana Estrada*}

ABSTRACT: The pandemic crisis that we are experiencing today has demonstrated thevulnerability of people with no Internet access. To begin with, during the obligatory quarantine, lots of students did not attend classes because they did not have Internet access. This means that they did not exercise their right to education, a fundamental right in the European Union. Besides that, those who are info-excluded are not able to communicate with anyone or obtain information, which leads to a digital divide problem that brings serial inequalities. It is also known that many people use the Internet to exercise their civil rights and participate in democratic processes, which once more reveals the disadvantages for those who do not have Internet connectivity. The truth is that, nowadays, Internet access is vital for the exercise of other fundamental rights that have to be safeguarded. All of these factors combined are proof of the importance of establishing Internet access as a fundamental right in the European Union.

KEYWORDS: fundamental rights - internet access - Italian case.

\footnotetext{
*Master's student in European Union Law at University of Minho.
} 


\section{Introduction}

This paper debates the possibility of enshrining the access to Internet as a fundamental right in the European Union. As we know, the Internet has a huge role nowadays in an individual's life. It is, first of all, an essential tool for lots of people to do their work, at the office or at home. Besides that, it also allows us to communicate with each other and to search for all sorts of information.

One movie that demonstrates the important role of Internet nowadays is "I, Daniel Blake", ${ }^{1}$ from 2016, which won the Palme d'Or, in Cannes, that year. This man, Daniel Blake, suffers a heart attack and his doctor prohibits him from returning to work., social security does not accept his doctor's recommendations and denies him employment and support allowance. Daniel decides to appeal and that is the moment he begins to run into difficulties: the forms to do the appeal are online, and Daniel does not know how to deal with computers nor how to access any online service. Consequently, he is totally lost and feels incapable of making the appeal. The situation seems impossible to solve until Daniel decides to learn how to use a computer. At the end, Daniel makes a great speech, where he declares that he is a "citizen, nothing more, nothing less" and deserves to be treated with respect.

This movie shows how an info-excluded person can have difficulties in doing some of the basic tasks of a citizen, like filing an appeal for getting employment and support allowance. An appeal that numerous people must make to get their rights and, sometimes, to survive. It shows how new technology and knowing how to use it can be essential nowadays for people to exercise their given rights.

All these points considered, it is realistic to say that access to the Internet is vital for some people to do their work and it is essential to ensure the exercise of some rights, starting with two fundamental freedoms online, freedom of communication and freedom of expression, through to other citizen's rights that are cardinal to human existence and subsistence.

This paper aims at, firstly, addressing the history of fundamental rights in the European Union and how they became essential values in this context benefiting from a higher level of protection.

Secondly, it refers to the Italian Declaration of Internet Rights, which establishes the Internet as a fundamental right, becoming the first European country and the second in the world to introduce a bill to protect the Internet rights of its citizens.

Then, it explores the concept of the human right to access the Internet, referring to the Internet's important role nowadays as well as the reaction of some European countries to these issues. Actually, some of them already stressed a right of Internet access as essential for this century.

\section{Fundamental rights in the European Union}

Fundamental rights are, nowadays, highly protected by the national courts of the Member States, but also by the European organs, especially by the European Court of Justice ("ECJ"), which is responsible for guaranteeing all European citizens their fundamental rights. Along with the ECJ and the national courts of the Member States, the European Court of Human Rights also has a very relevant role in the protection of human rights, having its own catalogue of human rights.

\footnotetext{
${ }^{1}$ Ken Loach, director and Rebecca O’Brien, producer, I, Daniel Blake (United Kingdom: BFI
} Distribution; France: Le Pacte, 2016). 
However, until getting these safeguards, the human rights of European citizens were subject change according to the will of the States. Changes gave the safeguards the emphasis they have today because, historically speaking, the individuals were not as protected as they are now. As Francis Fukuyama says in his work: "modern liberal democracy "recognizes" all human beings universally (...) by granting and protecting their rights." In the same line, John Murray defends that: "this underlies the historical evolution of the status of the individual in society, from the mere subject of a sovereign, then a citizen of his or her own stake to the modern era where the individual in a liberal democracy is him or herself a source of rights by virtue of the human dignity of the person."

After World War Two, the European countries started conceiving the dignity of man as the most important constitutional value, which "opened a new era in European constitutional thinking." Countries like Italy and Germany were the first countries to attribute the "bighest importance to human values and fundamental rights." Besides that, this concern about the protection of human rights took larger proportions, leading to the Universal Declaration on Human Rights, in 1948, adopted by the United Nations and later to the European Convention on Human Rights, an agreement concluded in 1950 and adopted by the Council of Europe. Nine years later, in Strasbourg, the European Court of Human Rights was founded in order to assure the challenges assumed in the Convention.

Later, the Treaty of Rome was signed by Belgium, France, Italy, Luxembourg, the Netherlands and West Germany which created the European Economic Community.

However, this founding Treaty did not mention nor protect any human rights. Due to that, the ECJ's constitutional role of protecting "the individual from breaches of their fundamental rights" ${ }^{\prime}$ was doubtful and weak since that exercise cannot be done "unless there is a credible legitimate basis for doing so."”

Given this, the first idea was to create "from the Treaty of Rome a supranational constitutional charter" ${ }^{\prime 8}$ of fundamental rights. This Charter would predict the doctrine of direct effect which allowed the individual to question the "compatibility of national measures with Community law", to uphold their individual rights.

But that did not solve the ECJ's problem, since the Treaty of Rome itself continued not to protect fundamental rights and hence the legitimacy of the Court to defend these rights was still doubtful.

Finally, in 1974, the Court takes a step forward and declared "that respect of fundamental rights forms an integral part of the general principles of Community law" ${ }^{10}$ and affirms its competence to protect those rights within the Unions' European scope. Its legal action would be guided by "an unwritten or enumerated catalogue of rights inspired

\footnotetext{
${ }^{2}$ Francis Fukuyama, The end of history and the last man (New York: The Free Press, 1992), 202.

${ }^{3}$ John L. Murray, "Fundamental rights in the European Community legal order", Fordham International Law Journal, v. 32, no. 2 (2009): 531-550, accessed April 28, 2020, https://heinonline.org/HOL/ Page?handle=hein.journals $/$ frdint32\&collection=journals\&id $=537 \&$ startid=\&endid $=556$.

${ }^{4}$ Rainer Arnold, "A Fundamental Rights Charter for the European Union”, Tulane European \& Civil Law Forum, v. 15, no. 15-16 (2001): 43-60, accessed April 28, 2020, https://heinonline.org/HOL/ Page?handle=hein.journals $/$ teclf15\&collection=journals\&id=47\&startid=\&endid $=64$.

${ }^{5}$ Arnold, "A Fundamental Rights Charter", 45.

${ }^{6}$ Murray, "Fundamental rights", 532.

${ }^{7}$ Murray, "Fundamental rights", 532.

${ }^{8}$ Murray, "Fundamental rights", 533.

${ }^{9}$ Murray, "Fundamental rights", 533

${ }^{10}$ Murray, "Fundamental rights", 534.
} 
by the constitutional traditions of the Member States and international human rights treaties to which the Member States subscribed." 11

The role of the Member States also has to be pointed out: it was the numerous preliminary rulings made by their national courts that led to ECJ's most important decisions in this field. In fact, it was the Members States who triggered the Court for it to ensure the protection of human rights and forced the establishment of a catalogue which protected those rights. Moreover, they stirringly accepted the "Court's impact in the field of fundamental rights."

The following years were better for human rights: the Single European Act of 1986 contained "buman rights references" 13 and later, in 1997, the Treaty of Amsterdam contained an article (Article 6) promoting the fundamental rights "as general principles of Community Law", which had to be respected by the European Union as guaranteed by the European Convention on Human Rights.

Both the constitutional traditions common to the Members States and the European Convention were important sources for the ECJ's rulings about fundamental rights cases. However, the ECJ always bore in mind that "the nature and scope of a fundamental right must be determined autonomously in Community law", ${ }^{14}$ despite how difficult it could be given that there was not any written and approved catalogue of human rights. Besides that, it was necessary to differentiate the European legal order, safeguarded by the ECJ and the "international system of the European Convention."15

Therefore, and in order to maintain the European Treaties as they were, without any amendments, "the German Presidency of the EU proposed a Charter of Fundamental Rights for the Union", ${ }^{16}$ which would enshrine and protect the European citizens' fundamentals rights.

At the Nice Summit of 2000, the governments of the Member States tabled this proposal, "through the 'solemn proclamation' of the EU Charter of Fundamental Rights."17 This Charter, for the first time in the European Community Order, allowed the reaffirmation and development of fundamental legal provisions concerning human rights, which were mainly derived from the constitutional traditions and international obligations of the Member States. ${ }^{18}$ At the end, this Charter wrote down the catalogue of unwritten general principles of Community Law that had been serving as a guideline for the ECJ in the preceding years.

After some disagreements between Member States on whether the Charter should be included in the Treaty or not, it was decided that the Charter should have the same legal value as the Treaties, "being acknowledged as a mandatory legal force." 19

This binding nature is consecrated in Article 6 of the Treaty of Lisbon, which

\footnotetext{
${ }^{11}$ Murray, "Fundamental rights", 534.

${ }^{12}$ Murray, "Fundamental rights", 536.

${ }^{13}$ Murray, "Fundamental rights", 536.

${ }^{14}$ Murray, "Fundamental rights", 538.

${ }^{15}$ Murray, "Fundamental rights", 539.

${ }^{16}$ David Anderson and Cian C. Murphy, "The Charter of Fundamental Rights: History and Prospects in Post-Lisbon Europe”, EUI Working Papers Law 2011/08, 2011, accessed April 28, 2020, https:// papers.ssrn.com/sol3/papers.cfm?abstract_id=1894386.

${ }^{17}$ Murray, "Fundamental Rights," 539.

${ }^{18}$ Gheorghe Dinu and Raluca Antoanetta Tomescu, "The European Union Charter of Fundamental Rights. The Treaty of Lisbon's Objectives and Principles", Contemporary Readings in Law and Social Justice, v. 9, no. 2 (2017): 229-235, accessed April 28, 2020, https:// heinonline.org/HOL/Page?handle=hein. journals $/$ conreadlsj9\&collection $=$ journals\&id=385\&startid=\&endid $=391$.

${ }^{19}$ Dinu and Tomescu, “The European Union Charter of Fundamental Rights”, 230.
} 
came into force in 2009, along with the Charter. This Article confirms another important change related to the protection of fundamental rights in European Union: the EU accession to the European Convention of Human Rights, "which have as effect guaranteeing a double level of protection for the individual. Therefore, if the citizens of the EU will not win in regards to a breach of their fundamental rights in front of a Court of Justice, they will have the option of addressing the Court of Justice of the European Union for Human Rights, invoking a breach of the European Convention."20

The EU Charter is now in force, with compulsory legal force, becoming accessible to all European citizens. It guarantees and consolidates all human rights which have got protection within the European's scope.

For a better understanding of the dimension of a human right, consider the right to education, protected by Article 14 of the EU Charter. By virtue of it being a human right, the State has to guarantee to all individuals this right freely, which means that it has to take all the necessary measures to provide education for everyone. That implies, in some cases, providing school buses for picking up students that do not have personal transport to get to school. ${ }^{21}$ In other cases, the State has to provide to the neediest students the school textbooks and, even, school material. All these governmental actions have to be taken in order to guarantee that every citizen has access to education. This is what is meant by a fundamental right: it is extended to everyone and defines a State's duty to ensure that right is being guaranteed.

Regarding Internet access as a fundamental right, which will be explored below, it is also a subject of debate because of the on-going pandemic. . In fact, COVID-19 has made evident the digital divide which brings inequalities that have to be overcome. Researcher Teresa Freixes in her "The Universal Right to Internet Access Manifesto" talks about precisely that and underlines how COVID-19 has revealed the importance of declaring Internet access as a fundamental right. ${ }^{22}$

At the same time, the United Nations Secretary-General, António Guterres, also pointed out how the corona virus has demonstrated the digital exclusion that exists around the world, upholding the importance of guaranteeing affordable Internet access for everyone. ${ }^{23}$

In fact, the current pandemic is a perfect demonstration of the importance of the Internet access and how its lack can disadvantage people, preventing them from exercising other fundamental rights, such as the right to education. That is why it is important to talk about a human right to Internet access and the steps that must be taken to enshrine it.

\section{Access to internet as a fundamental right}

\subsection{Italy is the first country to issue an Internet bill of rights which contains the right to Internet access as fundamental right}

All Member States of the European Union are bound by the constitutive

\footnotetext{
${ }^{20}$ Dinu and Tomescu, “The European Union Charter of Fundamental Rights”, 232.

${ }^{21}$ The article 73 of the Constitution of the Portuguese Republic enshrines the right to education for all citizens, which means that the State has to guarantee the access to education for everyone. To do so, it has to provide means of transports to ensure that everyone can go to school and can enjoy that access. ${ }^{22}$ Teresa Freixes, "The Universal Right to Internet Access Manifesto", 2020, accessed September 18, 2020, https://universalinternetaccessmanifesto.com/the-universal-right-to-internet-acces-manifesto/.

${ }^{23}$ ONU: mundo precisará de US\$ 428 bilhões para conectar todos à internet até 2030”, ONU News, September 18, 2020, https://news.un.org/pt/story/2020/09/1726652 .
} 
Treaties, which, since 2009, are consolidated in Treaty of Lisbon, as well as by the Charter of Fundamental Rights of the European Union, a catalogue of fundamental rights of all European citizens.

However, there are other rights that, eventually, can be considered fundamental rights. That happened in Italy, when, in 2015, an Internet bill of rights was introduced, whose one provision promoted a fundamental right to Internet access. According to Article 2 of the Declaration of Internet Rights issued in Italy, "access to the Internet is a fundamental right of all persons and a condition for their individual and social development." In this article, it is also pointed out that "public institutions shall take the necessary measures to overcome all forms of digital divide, including those created by gender, economic condition or a situation of personal vulnerability or disability."

This declaration of Internet rights underlies the importance of recognising and protecting the fundamental rights of every individual when they are online too, enshrining other rights like the right to online knowledge and education, net neutrality and the right to be forgotten.

The bill has no legal value nor is it intended to become a piece of national legislation. It was conceived in order to give a constitutional basis to the principles and rights of the Internet and to contribute to international debates about how the Internet should be governed.

\subsection{The human right to access the Internet}

Let us now explore the meaning of the human right to access the Internet.

All of these issues arise because of the unquestionable development of the Internet and new technologies. Nowadays, it is usual that everyone has access to Internet and, for a lot of people, that access is essential. Besides that, "the ubiquitous Internet offers unprecedented opportunities to disseminate information, opinion and ideas" and "it is fast becoming (...) the preferred mode for political participation, education, employment, commerce or personal activity." ${ }^{24}$ It is even possible to argue that individuals without Internet access "become socially disadvantaged or excluded" from the physical world.

In the Preamble of the Declaration of Internet Rights of Italy, it is stated that "the Internet is an increasingly important platform for the self-organisation of individuals and groups, and is a vital tool for promoting individual and collective participation in democratic processes as well as meaningful equality". The declaration also mentions the Internet's role as an economic platform, enabling innovation, fair competition and growth in a democratic context. All of this demonstrates the strong position that the Internet has in the $21^{\text {st }}$ century.

Tommaso Frosini goes further, stating that "technologies have represented and still represent a development of freedoms", ${ }^{26}$ like freedom of expression, freedom of communication and freedom of association. He also points out a new right: the informatic freedom, "perceived as the freedom to make use of computer in order to provide and obtain information of any kind or as the right to join the digital society and communicate to

\footnotetext{
${ }^{24}$ Tully Stephen, "A human right to access the internet - problems and prospects", Human Rights Law Review, v. 14, no. 2 (2014): 175-196, accessed May 28, 2020, https://heinonline.org/HOL/ Page?handle=hein.journals $/$ hrlr14\&collection=journals\&id=179\&startid=\&endid=200.

${ }^{25}$ Stephen, "A human right to access the internet", 177.

${ }^{26}$ Tommaso Edoardo Frosini, "Access to internet as a fundamental right", Italian Journal of Public Law, v. 5, no. 2 (2013): 226-234, accessed May 28, 2020, https:// heinonline.org/HOL/Page?handle=hein. journals $/$ itajpul $5 \&$ collection $=$ journals\&id $=229 \&$ startid $=\&$ endid $=237$.
} 
whoever." 27 This informatic freedom "is therefore a new right resulted from the evolution of technological society" and "qualifies as a new form of the traditional right of personal liberty." 28

Given the resources provided by the Internet, its access has to be considered as a social right, "like services such as education, health and welfare (...) that state's bodies must guarantee to their citizens." 29 Besides, "more and more the access to the Internet and the conduct of business via the Internet constitute the means by which individuals (...) exercise their citizenship's rights." ${ }^{30}$

Regarding the possibility of consecrating the human right to access the Internet, the truth is that international and European law has already debated that and it is consensual that it is necessary and important to ensure that access. For example, in 2010, the United Nations pointed out the Internet's role in realising "a range of buman rights", stating that "ensuring universal access to the Internet should be a priority for all States." 31 Additionally, previously in 2011, the Council of Europe "called upon its members to ensure that national policy recognises the objective of universal Internet access." 32 Just for curiosity, back in 2008, "the then New Zealand Minister of Justice suggested that Internet connectivity was almost a human right, similar to water and electricity." 33

Moreover, it is also possible to find some signs emerging of this right at the national level. For instance, in 2000, "Estonia declared Internet access to be a buman right 'essential for life in the 21 $21^{\text {st }}$ century."." 34 In France, throughout an important decision of the French Conseil Constitutionnel, "the court referred to the access to the Internet in terms of a fundamental right", ${ }^{35}$ considering that the freedom of expression implies freedom to access online services. Later, in 2010, the Finnish legislation established the access to the Internet as a "legal right" for over five million citizens. ${ }^{36}$ Switzerland and Spain are also aware of these actions "and may act in the next future in order to grant access to the Internet as a condition for the enjoyment of other rights." ${ }^{37}$ In turn, Italy becomes the first European country to issue an Internet bill of rights, declaring a human right the ability to access the Internet.

Having said that, it is notable that "there is emergent support for universal Internet access", ${ }^{38}$ given the role Internet plays in the $21^{\text {st }}$ century. The traditional freedoms of expression and communication require, today, this access to the Internet to be fulfilled. That leads to the emerging of "a very constitutional right to access to the Internet." 39 Moreover, Internet is an important means "by which individuals enter into relations with the state's powvers." ${ }^{40}$ Without Internet access, individuals are at disadvantage with regard to political participation.

In addition to all these factors, and using the previous human right mentioned (right to education), it is possible to say that now, given the pandemic that we are

\footnotetext{
${ }^{27}$ Frosini, "Access to internet", 226.

${ }^{28}$ Frosini, "Access to internet", 228.

${ }^{29}$ Frosini, "Access to internet", 230.

${ }^{30}$ Frosini, "Access to internet", 230.

${ }^{31}$ Frosini, "Access to internet", 233.

32 Stephen, "A human right to access the internet", 178.

${ }^{33}$ Stephen, "A human right to access the internet", 179.

${ }^{34}$ Stephen, "A human right to access the internet", 178.

${ }^{35}$ Frosini, "Access to internet", 232.

${ }^{36}$ Frosini, "Access to internet", 231.

${ }^{37}$ Frosini, "Access to internet", 232.

${ }^{38}$ Stephen, "A human right to access the internet", 180.

${ }^{39}$ Frosini, "Access to internet", 233.

${ }^{40}$ Frosini, "Access to internet", 230.
} 
living through, Internet access is more important than ever. The corona virus forced everyone to stay indoors and, if possible, work from home. The same thing happened to all the students in Portugal too. But, at the same time, students had to continue their classes to finish the school year. The solution found, and maybe the only possible one, was to have classes online, using platforms where teachers could gave lessons and guided their students in the best way possible. Obviously, distance learning is only possible if students have access to Internet. If they do not have that access, it is impossible to attend the meetings with teachers and the right to education might be jeopardised. That is why the government, since the beginning, took (and is taking) measures to ensure that all the students have access to a computer. However, even with these government attempts to guarantee education for all, there were students who were excluded and did not have classes due to not having computer at home (nearly $20 \%$ of students). In response to that, the government proposed to offer computers with Internet access to over 300,000 students of needy families in order to combat social inequalities felt in the distance learning. ${ }^{41}$ So, in addition to ensure Internet access, it is also necessary to ensure students have electronic devices so they can enjoy that access. Bearing in mind the actual situation, only with Internet access and computers which have that access is it possible to safeguard the essential right to education.

What is more, the new virus is a perfect case to strengthen the relevance of Internet access today. To begin with, the quarantine forced lots of people to work from home, which is impossible without Internet access. Those who do not have that access are clearly in a disadvantaged position compared to those who do.

Besides, and considering the period when everyone had to stay at home, the Internet was the best and maybe indispensable tool to perform many activities that would otherwise have not been possible to do while staying at home. In fact, Internet allowed people, at any time of the day, to communicate and to get information about what was going on. This implies that, besides being a way through which an individual can, for example, watch a movie or chat with friends, Internet access is also a tool for people to communicate and be informed, which are individual freedoms guaranteed for everyone, and especially important if it is the only way that those freedoms can be exercised.

Finally, the Internet, during the quarantine, was also important and helpful since it allowed people to do practical daily things such as buy food without leaving home. And that is no less important, since, once more, those who did not have Internet access were disadvantaged and had to risk their health to get food by going to a supermarket.

It's safe to say that the way Internet access embraces a world of rights and the fact that it facilitates a lot of daily actions is so considerable that it has to be considered a fundamental right.

So, to conclude, the access to Internet has to be considered as a human right because it is a tool that permits the exercise of citizenship's rights, like freedom of expression and communication and right to education, which are already humans rights ensured and protected by governments.

\footnotetext{
${ }^{41}$ Margarida Lopes, "Governo vai doar computadores com acesso à internet a 300 mil alunos de famílias carenciadas”, Human Resources, July 2, 2020, accessed July 3, 2020, https://hrportugal. sapo.pt/governo-vai-doar-computadores-com-acesso-a-internet-a-300-mil-alunos-de-familiascarenciadas/.
} 


\subsection{The possibility of a European human right to access the Internet}

At the moment, "none of the existing buman rights treaties contemplate a self-standing right of Internet access." the access to the Internet as a fundamental right of individuals in the relevant legal systems, even if at different levels: some in the constitutions, like Estonia, Greece (..); some by laws, like Finland; some by the case law of the respective courts, like France." 43

The problem is that even those who introduced legislation mandating Internet access "are not acting under any perceived obligation to provide a legally enforceable entitlement for individuals." ${ }^{44}$ So, in practice, the governments do not have any legal obligations to provide Internet access to individuals. Of course that would be difficult, since "this would entail, for example, the infrastructure necessary for Internet connectivity." 45 Instead, Internet access within Europe has been perceived as prohibiting States from "interfering with an individual's ability to connect to the Internet and access any material." 46

However, Italy, throughout its Internet bill of rights, answered the need of a strong framework to protect the rights of Internet users, stablishing, undoubtedly, a human right to Internet access. Article 2 of the Italian Declaration is clear: "access to the Internet is a fundamental right for all persons"; "every person shall have the same right to access the Internet"; "this right must be ensured with respect to its substantive prerequisites, not only the mere possibility of connecting to the Internet"; "public institutions shall take the necessary measures to overcome all forms of digital divide, including those created by gender, economic condition or a situation of personal vulnerability or disability." ${ }^{\prime 7}$ This last point entrusts governments with the obligation to provide Internet access to everyone because it is their right. Despite being a non-binding document, this declaration can serve, at least, to guide and, eventually, influence debates and measures that can be taken on this topic.

Taking everything into consideration, it is not impossible to, at least, put on the table the possibility of a European human right to Internet access, given the developments achieved in some European countries. Considering that Internet is here to stay and will continue to be an essential part of our daily life, Internet access can easily be considered as a fundamental right for citizens. If freedom of expression and communication, the right to education, the exercise of citizenships and other implies, nowadays, the access to online services, it is almost impossible not to consider Internet access a human right in itself.

To support this argument, Article 19 of the Declaration of the Rights of Man and of the Citizen which states that everyone has the right to freedom of opinion and expression through any media, which, now, includes Internet. To do so, the access to online services is indispensable.

Thinking ahead, this human right to Internet access could be added to the EU Charter of Fundamental Rights, perhaps in Title II, which refers to liberties, since what is at stake is "informatic freedom" or in Title V, entitled Citizenship, since the Internet is increasingly important to the exercise of citizenships rights.

It is also of interest to mention the latest speech of Ursula von der Leyen, President of the European Commission, that refers to the importance of digital

\footnotetext{
${ }^{42}$ Stephen, "A human right to access the internet", 181.

${ }^{43}$ Frosini, "Access to internet", 232.

${ }^{44}$ Stephen, "A human right to access the internet", 180.

${ }^{45}$ Stephen, "A human right to access the internet", 181.

${ }^{46}$ Stephen, "A human right to access the internet", 181.

${ }^{47}$ Camera dei deputati. Commissione per i diritti e i doveri in internet, "Dichiarazione dei Diritti in Internet”, 2015, accessed May 2, 2020, https://www.camera.it/leg17/1174.
} 
technologies and how the European Union intends to promote Internet connectivity and digital public services, in order to make Europe technologically autonomous. ${ }^{48}$

This could not be more important nowadays, when COVID-19 has obliged us to use the Internet as a tool for almost everything, from taking classes online to working from home. Having Internet connectivity and digital public services would be appreciated and really valued, especially in the times that we are experiencing. Having universal Internet access, as a fundamental right for everyone, would solve a number of problems and inequalities suffered by those who currently lack this access.

\section{Conclusion}

With this paper, it is, now, possible to understand the concept of a human right to access the Internet and the possibility of its enshrinement in the EU Charter of Fundamental Rights.

Furthermore, it also aligns with the challenges embraced by the newest President of the European Commission, Ursula von der Leyen, who undertook to make major efforts to achieve a Europe more prepared for the digital age. She committed to update the Digital Education Action Plan, highlighting the potential resources that Internet can offer students. She also states that "digital literacy has to be a foundation for everyone."

To achieve these objectives, it is important to ensure that everyone has Internet access to avoid any disadvantage. The most legitimate and effective way to guarantee that right is by considering it as a fundamental right of all European citizens.

Certainty, Daniel Blake would agree with Ursula von der Leyen about the importance of digital literacy. Perhaps, he would also agree with me on the importance of the right to access the Internet: at least, he would have more chance to protect his rights and feel more like a citizen.

\footnotetext{
${ }^{48}$ Ursula von der Leyen, "Discurso sobre o Estado da União", Comissão Europeia, September 16, 2020, accessed September 17, 2020, https://ec.europa.eu/portugal/news/state-union-presidentvon-der-leyen-ep-plenary_pt.
} 